\title{
THE RESILIENCE OF CZECH REGIONS TO ECONOMIC CRISIS
}

\section{ODOLNOST KRAJŮ ČESKÉ REPUBLIKY VŮČI HOSPODÁŘSKÉ} KRIZI

\section{ING. ONDŘEJ SVOBODA}

\author{
Ing. Martin MAŠTÁLKA, Ph.D. \\ \begin{tabular}{l|l} 
Ústav regionálnich a bezpečnostnich věd & Institute of Regional and Security Sciences
\end{tabular} \\ Fakulta ekonomicko-správni Faculty of Economics and Administration \\ Univerzita Pardubice University of Pardubice \\ $\square$ Studentská 84, 53210 Pardubice, Czech Republic \\ E-mail: ondrej.svoboda@upce.cz,martin.mastalka@upce.cz
}

\begin{abstract}
Annotation
The concept of the regional resilience is defined as an ability of the region to restore the original level after the incident that causes significant negative deviation from equilibrium. As an example of the negative step change it could be considered not only the impact of the global economic crises but also natural and anthropogenic disasters. It is obvious that there are regions that are more resistant to such events than the others. The aim of the paper is to present an example of the possible quantification of the regional resilience. There are also four hypotheses evaluated in the article. The analytic part of the work is made upon the CZ-NUTS3 data sets and reflects the impacts of the 2008 economic crises. As a main methodological attitude it is used the correlation analyses. There are described the regional economic resilience pillars that would be able to help to explain the regional disparities in the regional resilience. The results of the analyses confirm the hypothesis that Human Capital, Regional Economic Performance, Innovation and R\&D activity are very important determinants.
\end{abstract}

\section{Key words}

regional development, Regional resilience, Recessionary shocks, Determinants of Regional resilience, Employment

\section{Anotace}

Pojem regionálni odolnost se týká schopnosti regionu obnovit svioj původni stav po události, jež představuje významnou negativni odchylku od rovnovážného stavu. Jako přiklad negativni skokové změny lze považovat řadu události počinaje dopady globálni ekonomické krize až po různé prírodni či antropogenni pohromy. V tomto ohledu je možné sledovat, že některé regiony jsou v určitém úhlu pohledu více či méně odolné. Cílem článku je ukázat některé z možných způsobů kvantifikace regionálni ekonomické odolnosti a ověrit hypotézy vztahujici se $k$ potenciálním pilírüum ekonomické odolnosti regionů. Průzkum regionálni ekonomické odolnosti je proveden na přikladu regionů NUTS 3 České republiky v návaznosti na dopady hospodárské krize v roce 2008. Hlavní výzkumnou metodou je korelačni analýza. Článek se zabývá pilíri regionálni ekonomické odolnosti, které maji schopnost vysvětlit regionální rozdily v odolnosti vǐči hospodárským krizím. Výsledky ukazuji, že mezi významné piliřre ekonomické odolnosti regionů patři kvalita lidského potenciálu, ekonomická výkonnost regionu a regionální inovačni a výzkumná aktivita.

\section{Klíčová slova}

regionálni rozvoj, odolnost regionů, hospodářská krize, determinanty regionálni odolnosti, zaměstnanost 
JEL classification: $R 00, R 10, R 11$

\section{Introduction}

Contemporary regional development issue is enriched with a conception of the regional resilience. It could be described as a skill of the region to manage abrupt negative events. The list of negative events that could influence the region is very long (Sýkora, 2010). The word resilience comes from the Latin word resilire that means "jump back". As a jump it is meant the ability of the region to return its social-economic system to the same level (equilibrium) as it was before the event that caused the imbalance. The concept of the resilience is known in many scientific disciplines, e.g. the physics uses it for an expression of a material elasticity or psychology used if for psychical resilience of the individual.

The regional sciences adopted the resilience concept from the environmental studies focused on the biological adaptation skills in various surrounding conditions (Hill, 1973). The inspiration for resilience adaptation into the regional sciences it were studies, especially from USA, that described reaction skills and adaptability to the exceptional emergencies (9/11 attacks in NY, Catherine Hurricane...) - e.g. Foster (2007).

There are researches who focused to the possibility of transferring the concept into the field of regional economy. Nowadays the concept is elaborated by the wide spectrum of scientists from the field of regional analysts, regional economists and economic geographers. Among the others it could be mentioned Martin (2012), Hill, Wial and Wolman (2008), Pendall (2010) and Foster (2007). In the Czech environment there are significant outputs of Kraft et al. (2011) and a team concentrated around Koutský (2012). Their aim of scientists is to describe impacts of the several deviations and disruptions such as economic recession, unexpected rise of the main regional rivals, unexpected plant closures, new technological challenges etc. (Simmie, 2010)

As mentioned above the concept of the regional resilience was adopted by the regional sciences from the field of environmental sciences (Gunderson, 2002). Ecological point of view served as an inspiration for the regional resilience concept called "ecological". The other attitude is the technical one - it is called the engineering resilience (Martin, 2012). A detailed description of these concepts is beyond the scope of this article.

The regional economy uses the issue very often for the evaluation of the Regional Economic Resilience (RER). It is understood as an ability of the regional social-economic system to resist the impact that could cause an equilibrium deflection. Studies of financial and followed economic regional impacts of crisis from 2008 are the typical example of the issue application (Kraft, 2011).

This article assumes the regional resilience as a resilience of the regional (local) economy to the economic shocks. Based on data of the NUTS 3 level (Czech administrative self-governed regions) it describes attitudes the regional resilience evaluation in the environment of the financial and economic crisis. The interpretation of differences in regional resilience is based on the analysis of the possible determinants of RER.

\section{Resilience and economic resilience concepts}

There are authors (e.g. Kraft et al. (2011) and Koutský et al. (2012)) who mention that the economic globalization brings the higher sensitivity of the region to economic swings. The open economy causes strong mutual dependency of the regions. In the moment of the economic problems this wave is able to generate strong susceptibility of the regions to economic and social shocks. Hand in hand with economic crisis of last few years, this issue is more and more focused. 
One of the research questions of the issue (Dawley, 2010) are as follows: What kind of attitudes and method could be used for the regional resilience evaluation? How to explain diversity in regional resilience? Which regional characteristics could be marked as determinants influencing regional resilience? For how long could last the negative impacts of the events in regions? Which of the attitudes (ecological or engineering one) is better for the examined region? Which tools (set of tools) would be better to use to strength the regional resilience?

It is not easy to design determinants impacting the regional resilience. On the base of the previous researches - e.g. Martin (2012), Foster (2007), Koutský (2012) - and regarding partial generalization there can be designed sets of meaningful factors of the regional resilience. The sets are divided into 4 sections:

- Regional Economic Performance,

- Innovation Activity and R\&D,

- Human Capital,

- Labour Market.

Potential factors can be seen as "pillars of regional economic resilience". Those pillars can be represented by a variety of indicators called "determinants of regional economic resilience". Analysis of the determinants of regional economic resilience (RER) may reveal the origin of inter-regional disparities (Kraftová, 2013). The basic question is to find the way of measuring RER.

The first step of inter-regional analysis it is the design of the reliable indicators system. There are "common" characteristics used for the measuring of the regional resilience - the regional product and the regional employment. Because of the problems with regional product data accessibility on the regional level, there is often regional employment dynamics chosen as an indicator. This attitude is obvious in the study of the UK economic-geographer Martin Ron (2012), who focused his work to impacts of the recessions studied through the long-term data of the employment on the NUTS I level of the UK regions.

The economic shocks indicate the decrease period (recession phase) and ensuing rise of the employment level (recovery phase). Simplified perceptive to employment data line can show it as a line consisting only from the recession and recovery phases. The recession phase begins in the point where the local maximum is reached and ends in the point of its local minimum (recovery phase is analogous). This determination is important for further construction of the time-line development characteristics reflecting the negative economic shock.

There are important characteristics used for the regional resilience evaluation of the negative economic shocks to the employment level (Martin, 2012):

- level of the employment decrease (percentage decrease of the regional employment level at the end of the recession phase compared to the level before the decrease - symbolised in this article as $\% \mathrm{~F}_{1}-$ where " $\mathrm{F}$ " expressed "Fall", number 1 expressed first period of decline),

- level of the employment rise (percentage rise of the regional employment level at the end of the recovery phase compared to the level at the beginning of the recovery - symbolised in this article as $\% \mathrm{R}_{1}$ - where "R" expressed "Recovery").

The other characteristics designed for the analyses mentioned in this article are as follows:

- the point of the beginning of the employment decrease (the point where the timeline reached its top of the growth - symbolised in this article as $\mathrm{P}_{1}$ - where "P" expressed "Peak"),

- the length of the period of decreasing employment level - recession phase (measured as number of quarters between moment of first peak (symbolised as $\mathrm{P}_{1}$ ) and first trough (symbolised as $\mathrm{T}_{1}$ ),

- the length of the period of increasing employment level - recovery phase (measured as number of quarters between moment of first trough $\left(\mathrm{T}_{1}\right)$ and second peak (symbolised as $\mathrm{P}_{2}$ ), 
- postponed impacts of the crisis measured by delay of recessive phase to the beginning of a nationwide decline (4Q2008 for Czech republic) - this characteristic is expressed in number of quarters - symbolised in this article as $\operatorname{Lag}_{\mathrm{P} 1}$ ),

- the intensity of the employment level decrease - rate of decrease (\% difference of the employment level in the recession phase divided by the no. of the periods in this phase symbolised in this article as $\% \mathrm{~F}_{1} \mathrm{r}$ - where " $\mathrm{r}$ " expressed "rate"),

- the intensity of the employment level increase - rate of increase (\% difference of the employment level in the recovery phase divided by the no. of the periods in this phase symbolised in this article: $\% \mathrm{R}_{1} \mathrm{r}$ ).

Practical experience (Svoboda, 2013) with analysing the impacts of the financial and economic crisis in 2008 shows that the most of the regions have two recessive phases with minimum time spacing (among which is usually only 2-4 quarters recovery phase). In such cases recovery phase is very short and due to that \%R1 revealing a little about the development of the whole time series over an extended period after the crisis. Based on this finding, there was designed a characteristic describing the percentage change (increase or decrease) in employment levels measured between the moments of the first trough (minimum of employment level after beginning of crises) and moment of the end the time series (for this article is the end of the time series in 3Q2012). This characteristic is symbolised as $\% \mathrm{CH}_{\mathrm{T} 1}$ - where "CH" expressed "Change". The rate of change in period is symbolized as $\% \mathrm{CH}_{\mathrm{T} 1} \mathrm{r}$. It represents the average percentage change in the level of employment per quarter in period from first trough (T1) to 3Q2012.

The regions with stronger resilience (comparing to others) can be considered the ones (Martin, 2012), that:

- have lower decrease of the employment level or the product in recession phase $\left(\% \mathrm{~F}_{1}<\right.$ average $\% \mathrm{~F}_{1}$ of all regions),

- the intensity of their decline rate in recession phase is below the average of the other regions $\left(\% \mathrm{~F}_{1} \mathrm{r}<\right.$ average $\% \mathrm{~F}_{1} \mathrm{r}$ of all regions),

- have postponed impacts of crisis comparing to national level $\left(\operatorname{Lag}_{\mathrm{P} 1}>0\right)$,

- the increase point came earlier than in national level $\left(\operatorname{Lag}_{\mathrm{T} 1}<0\right)$,

- have higher increase of the employment level or the product in recovery phase $\left(\% \mathrm{R}_{1}>\right.$ average $\% \mathrm{R}_{1}$ of all regions),

- the intensity of their recovery rate in recovery phase is above the average of the other regions ( $\% \mathrm{R}_{1} \mathrm{r}>$ average $\% \mathrm{R}_{1} \mathrm{r}$ of all regions),

- have higher change of the employment level or the product measured form recovery phase to the end of examined time series $\left(\% \mathrm{CH}_{\mathrm{T} 1}>\right.$ average $\% \mathrm{CH}_{\mathrm{T} 1}$ of all regions),

- the intensity of their change rate measured form recovery phase to the end of examined time series is above the average of the other regions $\left(\% \mathrm{CH}_{\mathrm{T} 1} \mathrm{r}>\right.$ average $\% \mathrm{CH}_{\mathrm{T} 1} \mathrm{r}$ of all regions).

\section{Research methodology}

The following part of the article is dedicated to the analyses of the determinant that are able to explain regional diversities. As a data source for analyses serve the Czech Statistical Office datasets (ČSÚ, 2012) of the CZ NUTS 3 regions. As a basic point for the determinants testing it is chosen the year 2007. It represents the last year, when financial crisis haven't influenced the real economic indicators and indexes (Kraft, 2011). The only exception used in the analyses is the Highest Educational Attainment (because of the data availability - census 2011). This indicator is linked to the year 2011, but there is assumption that structure of education in 2007 was comparable to the structure in the year 2011. So we can use it as determinant of RER.

Measuring of regional economic resilience is based on quarterly time series of regional employment level. This series are rearranged by the X-12-ARIMA method with the goal to get seasonal adjustment of regional series (remove the seasonal fluctuation from time series). To find the break points (peaks local maximums and troughs - local minimums), the time series are rearranged by the Hodrick- 
Prescott Filter (HP filter - the parameter lambda $=2$ ). Those arrangements were made with the Gretl software, ver. 1.9.9.

The correlation analyse is made upon the prepared data. There are assessed relations between all determinants (see Tab no. 2) and the impact of the economic recession into the region (measured by followed characteristic: $\left.\% \mathrm{~F}_{1}, \% \mathrm{R}_{1}, \% \mathrm{CHT}_{1}, \mathrm{Lag}_{\mathrm{P} 1}, \% \mathrm{~F}_{1} \mathrm{r}, \% \mathrm{R}_{1} \mathrm{r}, \% \mathrm{CH}_{\mathrm{T} 1} \mathrm{r}\right)$. Each correlation is evaluated on the input data contains 14 rows (14 data corresponding to the 14 Czech NUTS 3 regions) and two columns (one of the determinants for the year 2007 and one of the characteristics of RER). Because there is not possible to prove the normality of dataset base, the Spearman's correlation coefficient was used.

The specific objective of the research is to test the following four hypotheses:

H1: The level of regional economic performance reduces the size of the decline in regional employment levels $\left(\% \mathrm{~F}_{1}\right)$.

H2: The intensity of R\&D and innovation activities increase growth of regional employment levels measured from first trough $\left(\mathrm{T}_{1}\right)$ to end of examined time series in 3Q2012 $\left(\% \mathrm{CH}_{\mathrm{T} 1}\right)$.

H3: The quality of human capital increase growth of regional employment levels measured from first trough $\left(\mathrm{T}_{1}\right)$ to end of examined time series in 3Q2012 $\left(\% \mathrm{CH}_{\mathrm{T} 1}\right)$.

$\mathrm{H} 4$ : Unemployment rate decreases growth of regional employment levels in the recovery phase $\left(\% \mathrm{R}_{1}\right)$.

\section{Analyse results}

Regions that have some characteristics under (for $\% \mathrm{~F}_{1}, \% \mathrm{~F}_{1} \mathrm{r}$ ) and above (for $\% \mathrm{R}_{1}, \mathrm{CH}_{\mathrm{T1}}, \mathrm{Lag}_{\mathrm{P} 1}, \% \mathrm{R}_{1} \mathrm{r}$, $\% \mathrm{CH}_{\mathrm{T} 1} \mathrm{r}$ ) the average values can be considered more resilient (bold items in Tab 1) compared to the other regions. Some regions have only two break points (e.g. Hl. m. Praha $-\mathrm{P}_{1}$ and $\mathrm{T}_{1}$ ). These regions haven't second peak $\left(\mathrm{P}_{2}\right)$. Due to that fact there aren't values for recovery phase $\left(\% \mathrm{R}_{1}, \% \mathrm{R}_{1} \mathrm{r}\right)$. Their recovery phase is not closed and it possible to calculate only $\% \mathrm{CH}_{\mathrm{T1}}$.

From the view of $\% \mathrm{~F}_{1}$ and $\% \mathrm{CH}_{\mathrm{T} 1}$ there are four resilient regions: Hl. m. Praha; Středočeský region, Plzeňský region a Jihomoravský region, that have together $\% \mathrm{~F} 1$ below $\left(\% \mathrm{CH}_{\mathrm{T} 1}\right.$ above $)$ the average. From this point of view there are also free "non-resilient" regions: Jihočeský region $\left(\% \mathrm{~F}_{1}=6.27 \%\right.$; $\left.\% \mathrm{CHT}_{1}=-1.51 \%\right)$, region Vysočina $\left(\mathrm{oF}_{1}=8.32 \% ; \mathrm{CCH}_{\mathrm{T} 1}=0.94 \%\right)$, Moravskoslezský region $\left(\% \mathrm{~F}_{1}=6.30 \% ; \% \mathrm{CH}_{\mathrm{Tl}}=1.12 \%\right)$.

Tab. 1: Characteristic of RER - NUTS 3 in the Czech Republic

\begin{tabular}{|c|c|c|c|c|c|c|c|}
\hline Region NUTS 3 & $\% \mathrm{~F}_{1}$ & $\% R_{1}$ & $\% \mathrm{CH}_{\mathrm{T} 1}$ & $\operatorname{Lag}_{P 1}$ & $\% \mathrm{~F}_{1} \mathbf{r}$ & $\% \mathrm{R}_{1} \mathbf{r}$ & $\% \mathrm{CH}_{\mathrm{T} 1} \mathrm{r}$ \\
\hline \multirow{14}{*}{$\begin{array}{l}\text { hl. m. Praha } \\
\text { Středočeský kraj } \\
\text { Jihočeský kraj } \\
\text { Plzeňský kraj } \\
\text { Karlovarský kraj } \\
\text { Ústecký kraj } \\
\text { Liberecký kraj } \\
\text { Královéhradecký kraj } \\
\text { Pardubický kraj } \\
\text { kraj Vysočina } \\
\text { Jihomoravský kraj } \\
\text { Olomoucký kraj } \\
\text { Zlínský kraj } \\
\text { Moravskoslezský } \\
\text { kraj }\end{array}$} & 4.62 & - & 2.65 & 2 & 0.58 & - & 0.53 \\
\hline & 2.59 & - & 6.15 & $\mathbf{0}$ & 0.52 & - & 0.61 \\
\hline & 6.27 & 1.12 & -1.51 & -2 & 0.78 & 0.28 & -0.17 \\
\hline & 4.03 & 2.86 & 2.27 & -2 & 0.50 & 0.71 & 0.25 \\
\hline & 4.96 & 4.13 & -0.65 & -1 & 0.99 & 1.03 & -0.06 \\
\hline & 3.39 & 1.42 & -1.71 & -2 & 0.42 & 0.36 & -0.19 \\
\hline & 2.27 & 3.64 & -0.35 & -1 & 1.14 & 0.52 & -0.03 \\
\hline & 3.75 & 1.55 & 0.73 & $\mathbf{0}$ & 0.75 & 0.78 & 0.07 \\
\hline & 5.64 & - & 2.08 & $\mathbf{0}$ & 1.13 & - & 0.21 \\
\hline & 8.32 & - & 0.94 & -3 & 0.49 & - & 0.94 \\
\hline & 2.54 & 2.08 & 2.88 & $\mathbf{0}$ & 0.51 & 0.52 & 0.29 \\
\hline & 7.47 & - & 5.61 & 1 & 1.07 & - & 0.80 \\
\hline & 8.12 & 3.40 & 1.76 & -3 & 0.74 & 1.13 & 0.25 \\
\hline & 6.30 & - & 1.12 & 0 & 0.63 & - & 0.22 \\
\hline Average & 5.02 & 2.53 & 1.57 & -0.79 & 0.73 & 0.67 & 0.27 \\
\hline
\end{tabular}


To explain the occurrence of interregional differences there were made correlation analyses. The results are displayed in the Tab. 2 and show correlation coefficients of potential determinants with all characteristics. $\operatorname{Lag}_{\mathrm{T} 1}$ is missing, because of no significant relationship with examined determinants.

As shown in Tab. $2 \mathrm{H} 1$ hypothesis is not confirmed. Despite significant relationship is proven (at a significance level of $5 \%$ ) for the negative relationship between GFCF (and productivity) and the rate of decrease of employment levels in recession phase $\left(\% \mathrm{~F}_{1} \mathrm{r}\right)$. It can be assumed that the productivity and GFCF slows down the speed of employment level decline and so that both have good impact to RER. Hypothesis H2 is confirmed (at a significance level of $5 \%$ ) for all analysed determinants (Percentage of innovating enterprises, Total R\&D expenditures, Number of employees working in R\&D). In addition, two determinants (Total R\&D Expenditures, Number of employees working in $R \& D)$ have positive influence to another characteristic of resilience - it postponed impacts of the crisis to region (positively correlates with $\mathrm{Lag}_{\mathrm{P} 1}$ ). Hypothesis $\mathrm{H} 3$ is confirmed (at a significance level of $5 \%$ ) only for "Highest educational attainment - University". The analysis revealed positive correlation between percentage of people with university level of education and $\% \mathrm{CH}_{\mathrm{T} 1}$ (growth of employment measured between first trough (minimum) and the end of time series in 2013Q3). Hypothesis H4 is not confirmed.

Tab. 2: Results of correlation analysis - Spearman's coefficient (significant values are bold)

\begin{tabular}{|c|c|c|c|c|c|c|c|c|}
\hline $\begin{array}{c}\text { Pillars of } \\
\text { RER }\end{array}$ & Potential determinants of RER & $\mathbf{\% F}_{1}$ & $\% \mathrm{R}_{1}$ & $\% \mathrm{CH}_{\mathrm{T} 1}$ & $\operatorname{Lag}_{\mathrm{P} 1}$ & $\%_{\mathbf{F}} \mathbf{r}$ & $\% \mathbf{R}_{1} \mathbf{r}$ & $\% \mathrm{CH}_{\mathrm{T} 1} \mathrm{I}$ \\
\hline \multirow{3}{*}{$\begin{array}{l}\text { Regional } \\
\text { Economic } \\
\text { Performance }\end{array}$} & $\begin{array}{l}\text { GDP per capita (at current } \\
\text { market prices) }\end{array}$ & -0.248 & -0.500 & 0.385 & 0.143 & -0.490 & -0.286 & 0.314 \\
\hline & $\begin{array}{l}\text { Labour productivity (GDP at } \\
\text { current market prices per } \\
\text { employees) }\end{array}$ & -0.024 & -0.643 & 0.099 & -0.066 & -0.758 & -0.405 & 0.191 \\
\hline & $\begin{array}{l}\text { Gross fixed capital formation per } \\
\text { capita (GFCF) }\end{array}$ & -0.182 & -0.262 & 0.376 & 0.138 & -0.736 & -0.476 & 0.358 \\
\hline \multirow{3}{*}{$\begin{array}{l}\text { Innovation } \\
\text { Activity and } \\
\text { R\&D }\end{array}$} & \begin{tabular}{|lll}
$\begin{array}{l}\text { Percentage } \\
\text { enterprises }\end{array}$ & of innovating \\
\end{tabular} & -0.262 & -0.095 & 0.688 & 0.290 & -0.442 & -0.167 & 0.609 \\
\hline & Total R\&D expenditures & -0.125 & -0.310 & 0.662 & 0.568 & -0.015 & -0.310 & 0.354 \\
\hline & $\begin{array}{l}\text { Number of employees working } \\
\text { in R\&D }\end{array}$ & -0.178 & -0.429 & 0.697 & 0.794 & 0.055 & -0.190 & 0.411 \\
\hline \multirow{4}{*}{$\begin{array}{l}\text { Human } \\
\text { Capital }\end{array}$} & $\begin{array}{l}\text { Highest educational attainment - } \\
\text { Compulsory }\end{array}$ & 0.209 & 0.357 & -0.626 & -0.346 & 0.266 & 0.048 & -0.538 \\
\hline & $\begin{array}{l}\text { Highest educational attainment - } \\
\text { Secondary vocational }\end{array}$ & 0.229 & 0.311 & -0.709 & -0.702 & 0.150 & 0.120 & -0.430 \\
\hline & $\begin{array}{l}\text { Highest educational attainment - } \\
\text { Secondary general with GCSE }\end{array}$ & 0.121 & -0.333 & 0.090 & 0.111 & -0.160 & 0.024 & 0.147 \\
\hline & $\begin{array}{l}\text { Highest educational attainment - } \\
\text { University }\end{array}$ & -0.223 & 0.024 & 0.907 & 0.625 & -0.042 & 0.096 & 0.629 \\
\hline \multirow{2}{*}{$\begin{array}{l}\text { Labour } \\
\text { Market }\end{array}$} & Economic activity level & 0.231 & 0.310 & -0.132 & -0.488 & 0.016 & 0.429 & 0.055 \\
\hline & Unemployment rate & 0.049 & 0.214 & -0.302 & 0.120 & -0.016 & -0.048 & -0.231 \\
\hline
\end{tabular}

Evaluated hypotheses proved the RER pillars relevance. Above mentioned "less resilient" regions are among those, that had in the year 2008 the lowest Human Capital level in the Czech Republic and also not so good situation from view of Economic Performance and Innovation and R\&D activities.

\section{Final results discussion}

The paper informs about the basic definitions of the Regional Resilience concept. It also specifies characteristics used for the regional resilience measurement. On the basis of the common data sets there are designed four pillars of the regional resilience. The analytical part of the paper evaluates four hypotheses. Two of them are proved to be true, two are not confirmed. All the analyses confirm the relevance of the designed RER pillars. 
Limits of the presented results are obvious. The limited available datasets are completed with the reality that only one shock was researched. The further research would spread the indicator sets and also enrich the research attitude with the non-economical point of view. There are lot of historical gaps in the modern history that would be involved, e.g. political changes, nature disasters... The issue Regional development is still at the beginning of its development. Upcoming realizations into the practical political and social-economic would show practical benefits of this explanation framework.

\section{Literature}

[1] ČESKÝ STATISTICKÝ ÚŘAD. Trh práce v ČR 1993-2011 [online]. 2012 [cit. 2012-08-30]. Dostupné z: $<\mathrm{http} / / / \mathrm{www} . c z s o . c z / c s u / 2012$ edicniplan.nsf/p/3103-12>.

[2] DAWLEY, S. Towards the Resilient Region? In SERC Discussion Paper [online]. 2010, č. 53 [cit. 2012-10-20]. Dostupné z: <http://eprints.lse.ac.uk/33523/1/sercdp0053.pdf>.

[3] FOSTER, K. A. A Case Study Approach to Understanding Regional Resilience. Working Paper 2007-08, Institute of Urban and Regional Development, University of California, Berkeley, [online]. 2007, s. $41 \quad$ [cit. 2012-09-14]. Dostupné z: $<$ http://www.iurd.berkeley.edu/publications/wp/2007-08.pdf $>$.

[4] GUNDERSON, L. H., HOLLING, C.S. Panarchy: understanding transformations in human and natural systems. Washington, DC: Island Press, 2002, xxiv, s. 507. ISBN 15-596-3857-5.

[5] HILL, E.; WIAL, H.; WOLMAN, H. Exploring regional economic resilience, Working Paper, Institute of Urban and Regional Development, No. 2008,04, [online]. 2008, s. 22 [cit. 2012-0915]. Dostupné z: <http://hdl.handle.net/10419/59420>.

[6] HOLLING, C. S. Resilience and stability of ecological systems [online]. In Annual Review of Ecology and Systematics, Volume 4, pp. 1-23. 1973, s. 22. [cit. 2012-09-02] Dostupné z: $<$ http://webarchive.iiasa.ac.at/Admin/PUB/Documents/RP-73-003.pdf .

[7] KOUTSKÝ, J., RUMPEL, P., SLACH, O. a kol. Profilace měkkých faktorů regionálního rozvoje jako nástroj posilování regionální odolnosti a adaptability. Certifikovaná metodika Ministerstva pro mistní rozvoj. [online]. 2012. s. 50. [cit. 2012-9-09] Dostupné z. $<$ http://zam.uur.cz/Rohrerova/Certifikovane-metodiky/10-Koutsky-WD-61-07-1.pdf .

[8] KRAFT, J. a kol., Východiska z krize. Cesty zmírnění negativnich efektů hospodářské krize v $\check{C} R$. Liberec: Technická univerzita v Liberci, 2011. ISBN 978-80-7372-787-1.

[9] KRAFTOVÁ, I., APPLOVÁ, P. Variabilita ve tvorbě bohatství: Ekonomický rozvoj a management regionů. In Sborník recenzovaných přispěvků Mezinárodní vědecké konference Hradecké ekonomické dny 2013 [online]. 2013, s. 329-328. ISBN 978-80-7435-249-2. [cit. 2013-10-04] Dostupné z: <http://fim.uhk.cz/hed/images/Sbornik_2013_dil_1.pdf>.

[10] MARTIN, R., GARRETSEN H., FINGLETON, B. Recessionary Shocks and Regional Employment: Evidence on the Resilience of U. K. Regions. Journal of Regional Science, vol. 52, no. 1, 2012, pp. 109-133. DOI: 10.1111/j.1467-9787.2011.00755.x.

[11] PENDALL R, FOSTER K. A., a COWELL, M. Resilience and regions: building understanding of the metaphor [online]. Cambridge Journal of Regions, Economy and Society, 2010, s. 22. [cit. 2012-10-02] Dostupné z: <http://cjres.oxfordjournals.org/content/3/1/71.full.pdf>.

[12]SIMMIE, J., MARTIN R. Evolutionary Approach to the Economic Resilience of Regions [online]. Cambridge Journal of Regions, Economy and Society, 2010, č. 3, s. 27-43. DOI: 10.1093/cjres/rsp029. [cit. 2012-10-02] Zostupné $<$ http://cjres.oxfordjournals.org/content/3/1/27.full.pdf + html $>$.

[13] SVOBODA, O. Hodnocení ekonomické odolnosti regionů soudržnosti [online]. In Sborník Hradecké ekonomické dny 2013. 2013, s. 252-257. ISBN 978-80-7435-249-2. [cit. 2013-10-04] Dostupné z: <http://fim.uhk.cz/hed/images/Sbornik_2013_dil_1.pdf>.

[14] SÝKORA, L. Současný stav a nové trendy: kritické zhodnocení české v kontextu světové sociální geografie [online]. In Sborník přispěvků z XXII. sjezdu České geografické společnosti 2010, $\quad$ s. $\quad 3 \quad$ [cit. 2012-09-15]. Dostupné $<$ http://konference.osu.cz/cgsostrava2010/dok/sykora_teze_formatovano.pdf $>$.

This article was made thanks to the support of the student grant competition SGFES03 Scienceresearch activity in the field "Economics and Management". 